
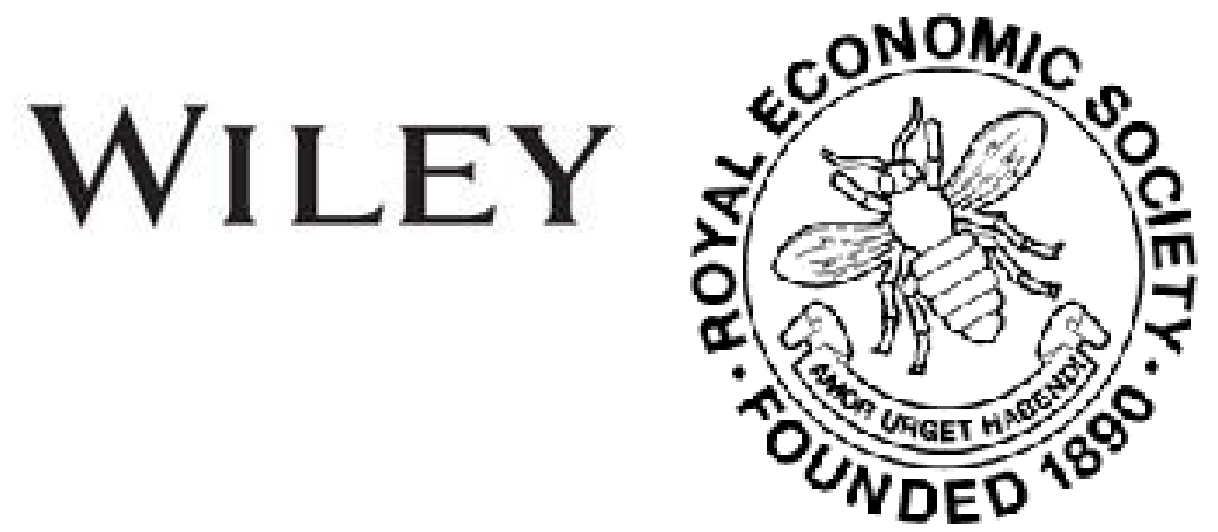

An Imperial Zollverein with Preferential Tariffs

Author(s): C. F. Bastable

Source: The Economic Journal, Vol. 12, No. 48 (Dec., 1902), pp. 507-513

Published by: Wiley on behalf of the Royal Economic Society

Stable URL: http://www.jstor.org/stable/2957310

Accessed: 27-06-2016 04:46 UTC

Your use of the JSTOR archive indicates your acceptance of the Terms \& Conditions of Use, available at

http://about.jstor.org/terms

JSTOR is a not-for-profit service that helps scholars, researchers, and students discover, use, and build upon a wide range of content in a trusted digital archive. We use information technology and tools to increase productivity and facilitate new forms of scholarship. For more information about JSTOR, please contact support@jstor.org.

Wiley, Royal Economic Society are collaborating with JSTOR to digitize, preserve and extend access to The Economic Journal 


\section{AN IMPERIAL ZOLLVEREIN WITH PREFERENTIAL}

TARIFFS

THERE could hardly be a better illustration of the close relation that exists between political and economic conditions than the revival of proposals for a customs union of the British Empire, to be accompanied by a departure from the established fiscal policy of Great Britain. The imperialist spirit excited by war has extended to the discussion of economic relations and has even suggested what is practically a return to an earlier system. For it is worthy of notice that the scheme of a Zollvercin with preferential tariffs between England and her Colonies was formulated sixty years ago by Torrens; while at the same time the policy of favouring colonial products had been carried to a point exceeding anything suggested now. ${ }^{1}$ It is beyond doubt that one strong influence in support of the Zollverein movement is the reaction against the economic doctrine on which the great reforms of Peel and Gladstone were based. Another contributory influence is the difficulty of applying general principles to what are felt to be new conditions which are believed to call for special treatment.

The inherent attractiveness of plans that gratify national sentiment. and appear to promise economic advantage tends to obscure the difficulties and dangers that they almost certainly involve. Thus the free trade aspect of a customs union commends it to many persons, who would object to its protective effect, just as its imperial side wins over upholders of British or Colonial protectionism. In this way a body of sentiment is created in favour of what may be regarded as marking a new stage in English development.

The process of joining different provinces or counties into a single fiscal area (Zoll-gebiet) is no new one. The abolition of the internal douanes in France at the Revolution, the commercial union of Scotland with England, and, later, of Ireland with Great Britain, and the establishment of internal free trade over the American Union are obvious instances; though the best known is, probably, that of

1 See Torrens: The Bulget, Letter vii., in which the system of preference is based on Ricardo's theory of foreign trade. Timber and sugar were articles in which the favour shown to the colonial product was considerable.

No. 48.-VOL XII. 
Germany by the founding of the Zollverein, which has given a special title for such combinations.

All the cases just mentioned possess, however, one important feature in common. The areas so brought together were adjacent. Their inclusion in a single customs region necessarily reduced the expense of guarding the frontiers, and relieved trade from inconvenient restrictions. ${ }^{1}$ This is, in truth, the great merit of a customs union, it makes trade completely free within the field of its operation, while it does not, or need not, involve any greater obstruction to intercourse with places outside its territory. Germany and Austria-Hungary are good instances of this beneficial operation.

There is, however, little need for insisting on the fact that no union of this kind is possible for the British Empire. So long as taxation of commodities has to be retained, custom house supervision will have to continue in the different detached parts of the Empire. ${ }^{2}$ The undoubtedly great benefits of a true Zollverein could not be realised under any arrangement applicable to the British dominions. A large portion of the total trade of the Empire is by the nature of the case seaborne, and this distinguishing feature effectually precludes the adoption of a form copied from the very different circumstances of Germany.

But another kind of fiscal unity has been suggested, viz., that in which the duties on goods would be so far equalised in Great Britain and the Colonies that there would be substantial identity in the taxes levied throughout Great and Greater Britain. Though more plausible in appearance, this plan is open to quite as serious objections. It fails to recognise the wide diversities in situation, material resources and character of the inhabitants of the various regions to be treated in the way proposed. Fiscal systems must be adapted to the countries in which they are employed, and it is this principle of relativity that decisively condemns any.attempt " to unite the several members of the British Empire, divided as they are from each other by the diameter of the globe in one fiscal system." ${ }_{3}$ The tax forms most effective in India are not those proper for the United Kingdom, nor could either be applied without alteration to Australia or South Africa.

Complete fiscal unity and the adoption of approximately similar financial arrangements in all the divisions of the Empire being both impossible, the cry for a Zollverein is in fact reduced to the advocacy of some expedient for facilitating intra-imperial trade. The commercial relations between the United Kingdom and the Colonies are, it is suggested, to be placed on a favourable fuoting. Each member is to do something to encourage trade with its fellows, and it would seem by

1 The customs line of Prussia alone in 1819 exceeded that of the Zollverein in 1862, though the latter comprised nearly twice the area of the former. Roscher, Finanzwissenschaft, \& 101, n. 1.

2 Even the Channel Islands are at present excluded from the British customs system.

${ }^{3}$ Earl Grey, Colonial Policy, vol. i., p. 8. 
implication, to discourage outside competition. Such a policy has little real affinity with that of a true Zollverein or a unification of tax systems; it rather resembles those 18th century commercial treaties of which the Methuen Treaty with Portugal may be regarded as the type. ${ }^{1}$ As England was then led to consume port wine and Portugal to use British woollens, so, in the future, is Great Britain to be induced to take Colonial corn and meat, the Colonist consuming English manufactures in return.

This is the real meaning-in American phrase, the true inwardness - of the somewhat magniloquent talk of a Zollverein or a commercial union of the Empire. No doubt behind the plans most in favour at present, there lies the idea of a wider and more rigorous action on the course of trade, tending ultimately to the transformation of the British Empire into a political and economic unit, closed in many important respects to foreign trade and living on its own resources. But it seems to be admitted that movement in this direction can only be by degrees, and accordingly it is as a tentative and slowly developing policy that the so-called Zollverein must be judged.

The economic conception on which it rests is clearly the superiority of home (or intra-imperial) over foreign trade. Exchange with other nations may, indeed, be good, but that between the different parts of the British Dominions is better. A further support is obtained in the often-asserted "self-sufficiency" of the Empire. Thus Mr. Chamberlain declares, "If we choose-that is to say, if those whom we represent choose-the Empire might be self-sustaining. It is so wide; its products are so various; its climates so different, that there is absolutely nothing which is necessary to our existence, hardly anything which is desirable as a luxury, which cannot be produced within the borders of the Empire itself." 2 But, as the Colonial Secretary is not slow to point out, "The Empire at the present time, and especially the United Kingdom-which is the great market of the world-derives the greater part of its necessaries from foreign countries, and it exports the largest part of its available produce - surplus produce-also to foreign countries." 3 That is to say, that instead of occupying a position of completeeconomic independence, in fact that aưrá $\rho \kappa \epsilon \iota a$ which was the ideal of Greek political philosophy, Greater Britain has commercial ties with every important country in the world, and has its well-being affected by their vicissitudes. ${ }^{4}$ Now to escape from this connexion is regarded as

1 The preferential arrangement in the Canadian tariff is closely parallel to the rebate of one-third on Portuguese wines provided in the Methuen Treaty. The articles of the treaty are given in Adam Smith,'Wealth of Nations, Bk. iv. ch. 6. For comment see Hewins, English Trade and Finance, pp. 129 sq.

2 Colonial Conference Report, 1902 [Cd. 1299], page 6. Cp. Sir C. Dilke's state. ment. "This empire lying in all latitudes produces every requirement of life and trade," Problems of Greater Britain, page 1.

${ }^{3}$ Colonial Conference Report, page 6.

4 "I confess that, to my mind, that is not a satisfactory state of things" is Mr. Chamberlain's comment. 
the goal of a sound economic policy, towards which all special measures must tend.

The shortest and curtest statement of this theoretical conception indicates sufficiently the line of criticism to which, from the economic standpoint, it is open. The whole course of English development has been in the direction of closer and fuller commercial relations with the various nations of the world. The progress of England has been intimately bound up with the growth of foreign trade, and great as has been her Colonial expansion her trade with outside countries has increased as rapidly. A detailed examination of the trade statistics, available in such abundance, amply supports the general proposition that the Colonial trade has never exceeded one-third, and for the last twenty years is nearer one-fourth of the total mass of British trade. ${ }^{3}$ To secure a self-sufficing Empire, it would be necessary to divert twothirds of the foreign, or one-half of the total, trade of the United Kingdom into the Colonial direction. The magnitude of the task is such as to suggest doubts as to its attainment, even in part.

Another point for criticism is found in the idea that the British Empire can with advantage supply all its needs from its own territory. In a sense it may be true, just as it was, perhaps, true that before the repeal of the Corn Laws the United Kingdom could have supported its population from its own soil. But the essential point is not the "technical" one of the possibility of obtaining the required supply, but the "economic" one of the cost at which that supply can be procured. Assertions that the British Empire produces all the necessaries and luxuries that man desires are beside the point-what has to be shown is that it can produce them in sufficient quantity without' additional sacrifice. But here experience is quite conclusive. In spite of hostile tariffs and other obstructions, the cheapest sources of supply for many articles of prime necessity are outside, not within, the empire. To take one example-the cotton industry must, it seems, depend for its very existence on the raw material afforded by the Southern States of the Union. Coffee, though a minor article, is similarly obtainable in the quantity needed only from abroad. Meat, corn, iron-ore, and wine are, and must be for a long period, obtained in great part by foreign trade. Thus the substantial basis of the pseudo-Zollverein proposal appears to be altogether untrustworthy.

Small encouragements may, indeed, be granted; reductions of duties may be arranged between Great Britain and the colonies: some extra imports may be placed on foreign goods; but, as the results of the Canadian preferential tariff show, 2 their effects are not likely to.

1 See the carefully arranged tables in Farrer, Free Trade versus Fair Trade, which come down to 1885 . For analyses of the latest returns see H. Cox, United Kingdom and its Trade, ch. vi., and Chiozza, British Trade and the Zollverein Issue.

2 For the effects of this tariff see Colonial Conference Report, pp. 83-129. Also Davidson, "The Canadian Preferential Tariff," Economic Journal, vol. x, pp. 540-552. Under the preferential arrangement, American trade with Canada has: increased at a greater rate than English trade. 
be important, and may, in some cases, be the opposite of what is desired.

There is still another aspect of the question which is rarely even mentioned, but which deserves consideration-that is the effect of preferences on the trade and policy of other nations. If the British Empire is to divert its commerce from foreign to colonial channels the void so left will not remain unfilled. New courses of trade will be created or fresh industries will arise through the direction of capital and labour to the work of supplying the goods no longer received from British lands. Even partial success in the realisation of the Zollverein idea in the British Empire would be a powerful stimulus to similar movements elsewhere, ${ }^{1}$ as well as an aid to the advocates of still higher tariffs in other countries. In truth the ideal to which the supporters of a Zollverein must, if they are consistent, look forward is that of a few great groups or confederations, each striving for economic independence, and rigidly excluding foreign products from its markets. The great nations of the world are to pay to one part of Chinese policy that sincerest flattery which lies in imitation.

Again, the framing of any system of preferential duties is a task which is certain to be surrounded by the most serious difficulties. It is comparatively easy to establish what are called "horizontal" reductions of duties. To take off one-third or one-fourth all round is a simple proceeding, but this crude process has such diverse effects on different interests that further adjustment becomes urgently necessary. To arrange any system for the several parts of the British Empire in such a way as to balance fairly the claims of the different sets of producers would be almost hopeless.

Behind this question of satisfaction to producers there is the graver one of the deep opposition between the interests of important classes both at home and in the colonies. In Great Britain and Ireland the so-called "agricultural interest," though it would welcome the exclusion of foreign produce, would not desire that colonial imports should take their place. The competition of Canada or Australia presses just as disagreeably on the farmer as that of Argentina or the United States. The great body of consumers would also stand in direct opposition to this policy of encouraging colonial trade at its expense. The traditions of the great Corn Law struggle are deep rooted enough to ensure that the policy would have to face keen and protracted opposition which would always imperil its continuance. The instability thence resulting would be a formidable economic danger, as well as a grave menace to those friendly relations that the scheme purports to strengthen and deepen. Like considerations apply, though perhaps in less degree, to the colonies. Manufactures developed

1 E.g., the plan of a customs union of the South American countries with the United States though now in abeyance might easily be revived. A Zollverein of the states of Central Europe is also a possibility to be taken into account, and in this case the arrangement would be economically advantageous. 
under the cover of protection have their most dangerous opponents in England. To open their market to the free entry of English goods is really to abandon the policy which colonial protectionists have strenuously upheld. In Canada the proximity of the United States would be a probable cause of friction. It can hardly be expected that a permanent discrimination against American products will not lead to complications and dissatisfaction, especially in districts settled by American immigrants; nor is it possible that there can be any economic isolation of the Dominion from her great neighbour. The Zollverein idea is likely to lead to political trouble both in England and in the colonies.

It is, however, often argued that the above mentioned difficulties are worth encountering for the sake of the solid advantages that would follow an economic union of the Empire. Some sacrifices may be called for in order to give greater strength to the realm as a whole. To this the obvious rejoinder is that no artificial device can accomplish anything of the kind. After, as before, the Zollverein the various parts of the Empire will be separated from each other and the connecting trade lines will be as open to attack. The food supplies of Canada or Australia would be as little available for England under blockade as those of America or Russia, while they would not be protected by neutral privileges. The very claim of self-sufficiency would amount to a challenge to those countries that the new commercial policy had excluded from their former markets. All the dangers that a scattered empire like the British is exposed to would be increased rather than diminished by any exclusive commercial policy.

How varied and difficult to foresee are the dangers that such a policy entails may be seen by considering the following case. One feature of the customs union plan would almost certainly be a limitation of intraimperial trade to British and Colonial vessels. ${ }^{1}$ In time of peace this would operate as a navigation law, but during war it would mean that all the vessels so engaged would be liable to capture, a risk that would make freight charges much heavier. The natural mode of relief would be to open the trade to neutral ships, which would be exempt from capture. Unfortunately, however, England herself has established the rule that neutral vessels engaging in a trade, closed in time of peace, are liable to capture. ${ }^{2}$ Thus, this one detail of economic policy might prove a serious hindrance to obtaining needful supplies.

Viewed on the whole the Zollverein system, or rather that spurious imitation of it which is all that is possible in the case of England and her possessions, is thoroughly bad. It rests on the false economic idea that trade between members of the same political body is better than trade with foreigners, a doctrine which is protectionism in essence.

'See the resolution on "The Coasting Trade" adopted at the Colonial Conference. Report, page xi.

2 Well-known as the "Rule of 1756." See Hall, International Law (4th ed.), pp. $660-3$. 
Its advocates fail to recognise the importance of foreign trade in the modern English state, and they also forget the lessons that the eighteenth and nineteenth centuries supply as to the effect of Colonial preferences and restrictions. In seeking to bring the mother country and the Colonies into closer union, they are really trying to introduce causes of discontent and political strife. The true line of progress lies in greater freedom of commerce for and with all countries, and to this a Zollverein of the kind suggested would be directly opposed. Happily, such a reversal of the sane and sober policy of the last fifty years has little chance of being attempted with success.

C. F. Bastable 